\title{
SUMMARY OF TABLES
}

0. Main indicators for the CMEA region .......... . 30

1. Production: Sources and Distribution

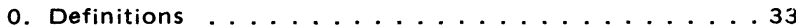

1. National product . . . . . . . . . . . . . 35

2. Employment and wages by economic sectors . . . . . 43

3. Gross investment and gross fixed assets by economic sectors . . . . . . . . . . . . 97

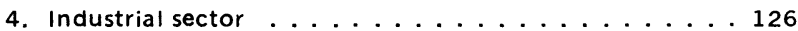

5. Agriculture .................. 236

11. Consumption and the Standard of Living

0. Definitions ................... . 275

1. Consumption and retail trade turnover .......276

2. Incomes and prices ............... . 282

3. Per capita consumption of staple foods . . . . . . . 287

4. Socio-economic indicators ............ . 295

111. Foreign Trade

0. Definitions and conversion factors ......... 305

1. Exports of CMEA countries . . . . . . . . . 308

2. Imports of CMEA countries ............... 313

3. Exports and imports of CMEA countries

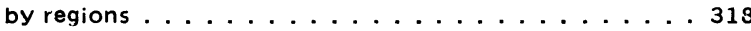

4. Exports and imports of CMEA countries by commodity groups . . . . . . . . . . . 346

5. CMEA foreign trade with the industrial West ............... 367

6. Austria's foreign trade with the CMEA countries . . . . 373

IV. Finance

0. Definitions ................. . . . 397

1. State revenue and expenditure ........... 398

2. Loans to enterprises, institutions and private households ............... . 418

3. Private savings deposits . . . . . . . . . . . . 422

4. Money in circulation . . . . . . . . . . . . . 424 